\title{
MAXIMIZING THE PROFIT OF A HPP CASCADE CONSIDERING HYDRAULIC LINK VIA RESERVOIRS
}

\author{
A.Y. Mahnitko ${ }^{1}$, J.H. Gerhards ${ }^{1}$, T.V. Lomane ${ }^{1}$, R.V. Varfolomejeva ${ }^{1}$, V.P. Oboskalov ${ }^{2}$, K.S. Koljasnikov ${ }^{2}$ \\ ${ }^{1-}$ Institute of Power Engineering, Riga Technical University, \\ Azenes str., 12/1, Riga, LV-1048, Latvia, \\ 2 - Ural Federal University, \\ Mira str.,19, Yekaterinburg, 620002, Russia. e-mail: mahno@eef.rtu.lv
}

At the conditions of market relationships and economic and financial independence of power companies, these are guided by the principle of achieving maximum efficiency in their actions. In the article is considered the problem formulation of HPP cascade operational mode determination, ensuring maximum profit from the sales of the generated electric power at the day-ahead market. Dynamic volumes of reservoirs are taken into account using the lag time between the waves of HPP water flow. The problem solution using the method of statistical modelling is approbated on the example of hypothetical cascade of three HPP. The results of the modelling of cascade operating regime are illustrated graphically. References 5, figures 2, table 1.

Key words: HPP cascade, regime, capacity, head level, time flow lag of water.

Introduction. Various forms of power economics management have used corresponding criteria for evaluating their efficiency [1-5]. The present form of financial and economic independence of power generation facilities requires review of new criteria for solving optimization problems and the most suitable solving methods, which take account of the present-day possibilities of computer technology. The present study addresses the task of determining the operating schedule of a cascade of HPPs that enables the sales of the electricity generated by it at a known price at the day-ahead market for obtaining maximum profit from its operation. The dynamic volumes of the water reservoirs are viewed considering the time of flow lag between the HPPs. The task is solved by means of statistical modelling. The proposed algorithm can also be implemented for a cascade of HPPs with a weekly regulation cycle.

Task statement. In condition of limited hydro-resource and set capacities of HPP cascade is needed to find the volume of energy deliveries at day-ahead market by providing maximal income from it sales according already known price prediction and day regulation of reservoirs. As for the revenue, in this case it can be reflected by the function:

$$
I=\sum_{i=1}^{n} \sum_{j=1}^{m} c_{i} \cdot P_{i j} \cdot \Delta t_{i} \rightarrow \max ,
$$

where $\Delta t_{i}$ is the duration of the calculation interval in hours; $P_{i j}$ is the electric capacity $(\mathrm{kW})$ of the $j$-th HPP in the $i$-th interval; $i$ is the number of intervals; $j$ is the number of HPPs in the cascade; $c_{i}$ is the price of electricity in the $i$-th time interval.

The capacity of the $j$-th HPP at any time moment $\mathrm{t}$ is determined by the formula

$$
P_{j t}=9,81 \cdot \eta_{j t} \cdot Q_{j t} \cdot H_{j t},
$$

where $g=9,81 \mathrm{~m} / \mathrm{s}^{2}$ is the gravity acceleration; $Q_{j t}$ is the flow of water through the turbines of the HPP; $H_{j t}$ is the hydraulic head of the HPP, determined as the difference between the levels of the head race and the tail race, m; $\eta_{j t}$ is the efficiency of the HPP, in relative units.

The limitations of that type of problem are written in the form of equations and inequalities regarding the levels of each water reservoir, regarding the volumes of each water reservoir, regarding the summary capacity of all the HPPs of the cascade (the electric capacity generated by the cascade over every $i$-th time interval), which link the technological limitations of the generated capacities of each HPP.

The equations include:

- the water-balance equations of every $j$-th HPP for any $i$-th time interval $\Delta t$ of the form [3]

$$
Q_{\text {top } j t}=Q_{\text {buttom } j k}\left(1-\frac{t_{g, i k}}{\Delta t_{i}}\right)+Q_{\text {buttom }(i-1) k} \cdot \frac{t_{g(i-1) k}}{\Delta t_{i}}+Q_{\text {inf low }, i j},
$$

where $Q_{\text {top } j t}$ is the water flow in the $i$-th interval for the $j$-th HPP; $t_{g, i k}$ is the travel time of the water flow in the $i$-th interval from the $\eta$-th (upstream) HPP located directly adjacent to the considered $j$-th HPP; $Q_{\text {inf low+, } i j}$ is the inflow of the river to the $j$-th HPP in the $i$-th interval: if the $j$-th HPP is the uppermost one then the value of this inflow is a sum of

(C) Mahnitko A.Y., Gerhards J.H., Lomane T.V., Varfolomejeva R.V., Oboskalov V.P., Koljasnikov K.S., 2016 
everyday and side inflow (see Figure 1). Otherwise, it is equal to side inflow; $Q_{\text {buttomij }}$ is the average value of water flow over the $i$-th interval into the tail race for the $j$-th HPP, determined by the expression [3]

$$
Q_{\text {buttom }, j t}=Q_{\text {inf low }+i j}+Q_{r i j}+\left(1-\frac{t_{g, i k}}{\Delta t_{i}}\right) \cdot Q_{\text {buttom } i k}+\frac{t_{g(i-1) k}}{\Delta t_{i}} Q_{\text {buttom }(i-1) k},
$$

where $Q_{r i j}$ is the average water flow from the water reservoir of the $\mathrm{j}$-th HPP over time interval $i$;

- limitations regarding the set filling volumes of the HPP water reservoirs at the end of the regulation period

$$
\sum_{i=1}^{n} Q_{i j}=\left(V_{0 j}-V_{\text {end } j}\right)\left(\Delta t_{i}\right)^{-1}, \quad j=\overline{1, m},
$$

where $V_{0 j}$ is the volume of the water reservoir of the $j$-th HPP at the beginning of the regulation cycle; $V_{\text {end } j}$ is the same, at the end of the regulation cycle.

Experimental part. The approbation of the algorithm for obtaining maximum profit from a HPP cascade in the considered formulation of the problem was performed on the basis of a hypothetical cascade consisting of three HPPs. The initial data for this cascade are presented in Table. An electricity price schedule at the Nord Pool Spot exchange with hourly data over a 24-hour period and the operating mode of each HPP of the considered hypothetical cascade are shown on Figure 1 and Figure 2. The same figure illustrates the results of the optimization of the operating regime of each HPP of the considered hypothetical cascade.

\begin{tabular}{|l|c|c|c|}
\hline \multicolumn{1}{|c|}{ Parameters } & I & II & III \\
\hline 1. Installed active power, $M W$ & 893.5 & 266 & 402 \\
\hline 2. Water level restriction from the top, $m$ & 37.5 & 24 & 12.9 \\
\hline 3. Water level restriction from the bottom, $m$ & 34 & 22 & 10.7 \\
\hline 4. The area of our reservoirs $S_{n}, m^{2}$ & 35000000 & 24900000 & 35800000 \\
\hline 5. Efficiency & 0.98 & 0.975 & 0.975 \\
\hline $\begin{array}{l}\text { 6. Water throughput through the turbine, } \\
\mathrm{m}^{3} / \mathrm{sec}\end{array}$ & 2900 & 2188 & 3642 \\
\hline
\end{tabular}

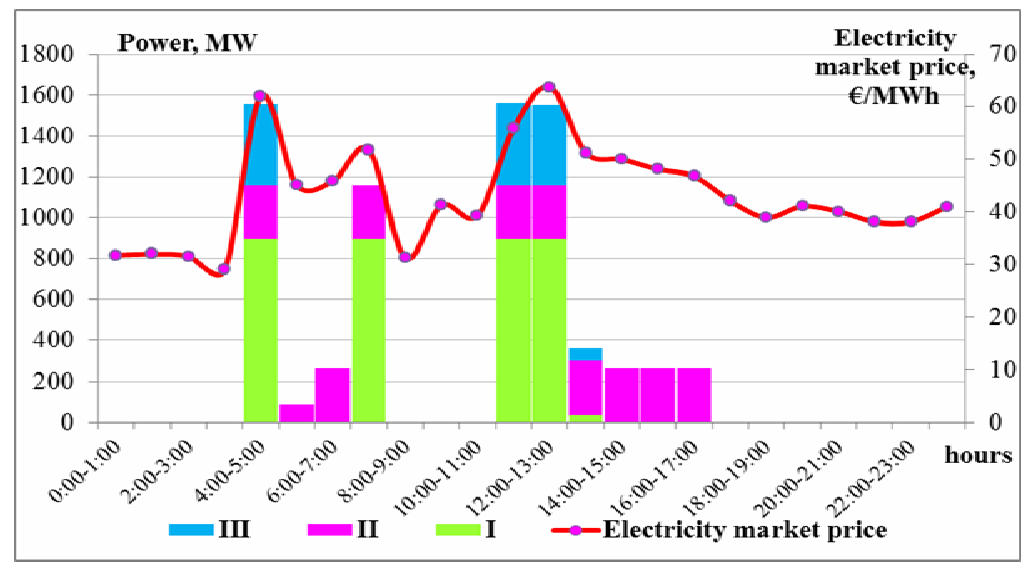

Fig.1

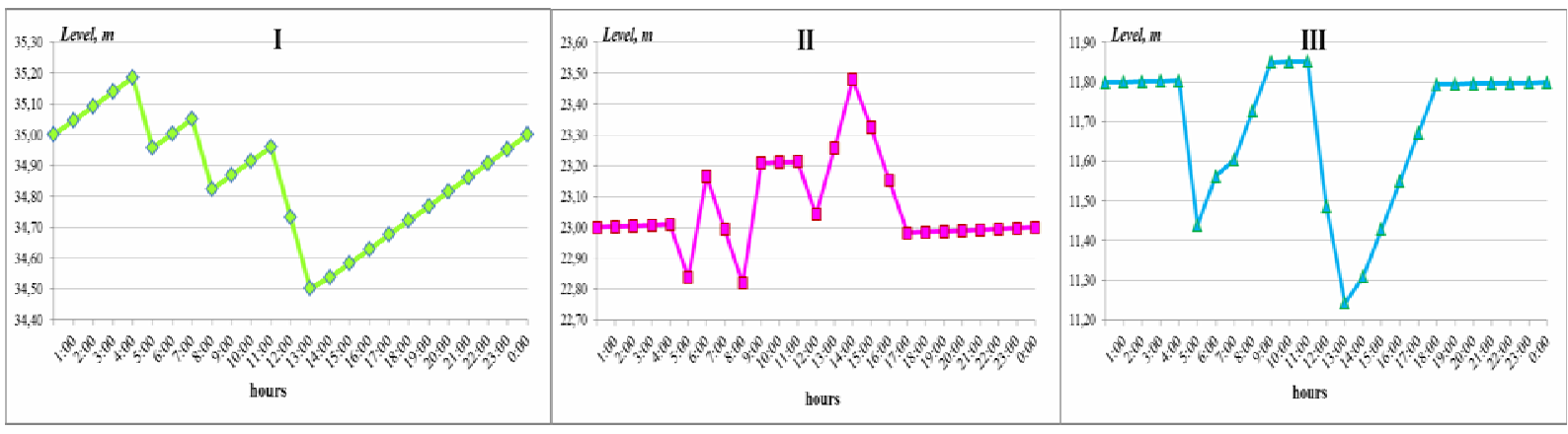

Fig.2 


\section{Conclusion.}

The proposed model of optimizing the operating mode of a cascade of HPPs, considering the hydraulic link between them at a 24-hour regulation cycle enables determination of the hourly amounts of sales of electricity generated by each HPP of the cascade ensuring them the maximum profit by selling it at the market (exchange). Using a statistic modelling method (Monte-Carlo) ensures simplicity in the implementation of the optimization algorithm in the presence of a large number of limitations.

1. Gornstein V.M. Optimal Operation Hydro Power Plants in Power Systems. - Moskva: Gosenergoizdat, 1959. - 248 p. (Rus)

2. Reznikovskii A.S., Rubinstein M.I. Modes Control of Hydroelectric Power Plants Reservoirs.- Moskva: Energiia,1974.-176 p. (Rus)

3. Tsvetkov E.V., Alyabysheva T.M., Parfenov L.G. Optimal Regimes of Hydropower Plants in Power Systems. - Moskva: Energoatomizdat, 1984. - 304 p. (Rus)

4. Radu Popa, Florica Popa, Bogdan Popa, Manuela Nicolescu. Optimal Operation of Cascade Hydropower Plants // U.P.B. Sci.Bull. Series D. - 2010. - Vol. 72. - Iss. 1. - Pp. 93-100.

5. Mahnitko A., Gerhards J., Linkevics O., Varfolomejeva R., Umbrasko I. Small Hydropower in Latvia and Intellectualization of its Operating Systems // Latvian Journal of Physics and Technical Sciences. - 2013. - Vol. 50 (6). - Pp. 3-15.

\section{ДОСТИЖЕНИЕ МАКСИМУМА ЭКОНОМИЧЕСКОЙ ЭФФЕКТИВНОСТИ РАБОТЫ КАСКАДА ГЭС} С УЧЕТОМ ГИДРАВЛИЧЕСКИХ ОБЪЕМОВ ВОДОХРАНИЛИЩ

А.Е. Махнитко ${ }^{1}$, докт.инж.наук, Я.Х. Герхард ${ }^{1}$, докт.инж.наук, Т.В. Ломан ${ }^{1}$, докт.инж.наук, Р.В. Варфоломеева ${ }^{1}$, докт.инж.наук, В.П.Обоскалов ${ }^{2}$, докт.техн.наук, К.С.Колясников ${ }^{2}$

1 - Институт энергетики Рижского технического университета, ул. Азенес, 12/1, Рига, LV-1048, Латвия,

2 - Уральский федеральный университет, ул. Мира, 19, Екатеринбург, 620002, Россия. e-mail: mahno@eef.rtu.lv

В условиях рыночных отнотений, хозяйственной и финансовой самостоятельности энергетических предприятий, последние руководствуются принципом достижения максимума экономической эффективности от своей деятельности. В статье рассмотрена постановка задачи определения графика работь каскада ГЭС, обеспечивающего получение максимального дохода от продажи выработанной им электроэнергии на рынке «на сутки вперед». Динамические объемы водохранилищ учитываются с помощью времени добегания волны расходов воды между ГЭС. Решение задачи методом статистического моделирования апробировано на примере гипотетического каскада из трех ГЭС. Результаты моделирования режима работы рассматриваемого каскада ГЭС иллюстрируются графически. Библ. 5, рис. 2, табл. 1.

Key words: каскад гидроэлектростанций, режим, мощность, уровень бьефа, время добегания.

\section{ДОСЯГНЕННЯ МАКСИМУМУ ЕКОНОМІЧНОЇ ЕФЕКТИВНОСТІ РОБОТИ КАСКАДА ГЕС З ВРАХУВАННЯМ ГІДРАВЛИЧНИХ ОБ'СМІВ ВОДОСХОВИЩ}

А.Е.Махнитко ${ }^{1}$, докт.інж.наук, Я.Х.Герхард ${ }^{1}$, докт.інж.наук, Т.В.Ломан ${ }^{1}$, докт.інж.наук, Р.В.Варфоломесва ${ }^{1}$, докт.інж.наук, В.П.Обоскалов ${ }^{2}$, докт.техн.наук, К.С.Колясников ${ }^{2}$

1 - Інститут енергетики Ризького технічного університету, вул. Азенес, 12/1, Рига, LV-1048, Латвія,

2 - Уральський федеральний університет, вул. Миру, 19, Скатеринбург, 620002, Росія.

e-mail: mahno@eef.rtu.lv

В умовах ринкових відносин, хазяйської та фінансової самостійності енергетичних підприємств останні керуються принципом досягнення максимуму економічної ефективності від своєї діяльності. У статті розглянуто постановку задачі визначення графіку роботи каскада ГЕС, щуо забезпечує одержання максимального доходу від продажу виробленої ним електроенергї на ринку «на добу вперед». Динамічні об'єми водосховищ враховуються за допомогою часу «добігання хвилі» витрат води між ГЕС. Розв'язування задачі методом статистичного моделювання апробовано на прикладі гіпотетичного каскаду з трьох ГЕС. Результати моделювання режиму роботи каскаду ГЕС, щцо розглядався, ілюстровано графічно. Бібл. 5, рис. 2 , табл. 1.

Key words: каскад гідроелектростанцій, режим, потужність, рівень б’єфа, час добігання. 